\title{
PERFORMANCE OF A WIND-SOLAR REVERSE OSMOSIS UNIT FOR BRACKISH WATER DESALINATION IN REMOTE AREA
}

\section{Samira S. Kassem ${ }^{1}$, Abd El-Hamid Z. Shokr ${ }^{2}$ and Suliman N. Suliman $^{2}$,G. Papadakis ${ }^{3}$}

\begin{abstract}
In this study, the operation parameters of the developed brackish solarwind reverses osmosis unit (BSWROU) were limited. As feed water pressure, feed water salinity and feed water $p H$ were constant. The feed temperature was the only operation parameter changed due to ambient temperature changing. Thus, the effect of feed temperature on different parameters was considered. However, due to the huge data recorded for the unit, the performance was evaluated for some months of year 2012. Theses months were elected to represent winter, spring, summer, and autumn seasons. These months included January, April, July and October. Also, the performance was evaluated as average values for all criteria for all year. The performance of the unit was evaluated using different criteria. These criteria are energy consumption for producing fresh water $\left(\mathrm{kWh} / \mathrm{m}^{3}\right)$, recovery percent $(\%)$ and concentration factor $(\%)$. The average values of these criteria during operation in year of 2012 were $2.7 \mathrm{kWh} / \mathrm{m}^{3}$, $44.7 \%$ and $1.82 \%$, respectively. It is evident that these values demonstrated good operation of BSWROU.
\end{abstract}

\section{INTRODUCTION}

$\mathrm{F}$ Tresh water is the most important source for life on the earth. However, Egypt, with the highest population in the area, is already considered to be in the water scarcity limit. Thus, there is an increasing need for desalted water to cope with the population growth and development (Al Bazedi et al., 2012). Furthermore, in the Egyptian deserts and rural areas, the supply of water and energy is the main

\footnotetext{
${ }^{1}$ Agricultural Engineer, Agricultural Engineering Research Institute, Agriculture Research Centre, Egypt.

2 Professor, Agricultural Engineering Department, Faculty of Agriculture, Alexandria University, Egypt.

${ }^{3}$ Professor, Agricultural Engineering Department, Faculty of Agriculture, Greece University, Athena, Greece.
} 
problem where great part of the rural population does not have access to the general electrical grid and water resources.

In spite of presence of large sources of brackish water in such areas, there is a shortage in fresh water. On the other hand, solar energy is abundant in these remote areas of Egypt, where the amount of sunshine hours is around $3500 \mathrm{~h}$ per year (Ahmad and Schmidt, 2002).

The study of the potential interface between desalination and renewable energy technologies such as solar and wind energy has increased significantly in the last five years. Considering that the energy requirements for desalination continues to be a highly influential factor in system costs, the integration of renewable energy systems with desalination seems to be a natural and strategic coupling of technologies (Phuse and Shelke, 2012). Furthermore, the major advantage of a hybrid system is that when solar and wind power production is used together, the reliability of the system is enhanced (Mahmoudi et al., 2008).

The water available through desalination techniques like reverse osmosis can be used for domestic or industrial purposes. Reverse osmosis has the potential to provide high quality drinking water and water for household applications. It can put into use to supply small towns or large cities (Russel, 2009). Reverse osmosis such as a desalination unit could be powered by renewable energy systems (Hunter and Elliot, 1994).

The potential role of desalination of brackish water as a source of fresh water in Egypt was discussed in different research papers using solar cell as a source of energy (E1-Kady and E1-Shibini, 2001; Liu et al., 2002; Ismail et al., 2012), but little research is found on studying the use of hybrid renewable energy systems such as solar and wind to power desalination unit of brackish water. Also, the experience in these areas in Egypt is essential for next years as the source of water from Nile has major troubles.

Banat et al. (2012) mentioned that the alarming water and energy crisis in many regions of the world can be eased by combining renewable energy with desalination technologies. Goosen et al. (2011) reported that the renewable energy driven desalination systems fall into two categories. The first includes distillation processes driven by heat produced directly by the renewable energy system, while the second includes membrane and distillation processes driven by electricity or mechanical energy produced by 
the renewable energy system. However, desalination refers to a water treatment process that separates salty water into a wastewater stream of high salt concentration and a fresh water stream of low concentration and is one of the principle alternative sources for fresh water available today (Abou Rayan et al., 2004).

$\mathrm{RO}$ is the one the widely used desalination technique in the world. It offers the distinct advantage over the other desalination techniques because it consumes low energy, provides a high quality final desalination process (Barron, 2006).

Desalination using renewable energy sources does offer the potential of providing a sustainable source of potable water for some communities, particularly those in arid areas (Abou Rayan et al., 2004). The successful renewable energy systems/desalination applications prove that the coupling of the two technologies is technically mature and capable to provide fresh water at a reasonable cost. Charcosset (2009) showed that the renewable energies such as solar, wind, and wave could drive membrane processes include reverse osmosis, membrane distillation and electro-dialysis. Each type of renewable energy has its own advantages that make it suited to certain applications. Almost none of them release gaseous or liquid pollutants during operation.

The coupling of RO with solar energy is a promising field of development in the desalination sector, with the potential to (i) improve its sustainability by minimizing or completely eliminating the dependence on fossil fuels and (ii) significantly reduce the operational costs of desalination plants (Wilf and Klinko, 2001). Thomson and Infield (2005) simulated and implemented a PVdriven RO with variable flow that was able to operate without batteries, designed for Eritrea. They performed laboratory tests to validate the model and control of the system: $3 \mathrm{~m}^{3} /$ day with a PV array of $2.4 \mathrm{kWp}$.

Ahmad and Schmid (2002) presented a design for a PV powered smallscale desalination system to be operated in remote areas of Egypt. It is estimated that the cost of producing $1 \mathrm{~m}^{3}$ of fresh water from the PV-RO system is $3.73 \$$.

Herold and Neskakis (2001) presented a small PV-driven reverse osmosis desalination plant on the island of Gran Canaria with an average daily drinking water production of $0.8-3 \mathrm{~m} / \mathrm{day}$. The plant was supplied by a stand- 
alone $4.8 \mathrm{~kW}$ photovoltaic (PV) system with additional battery storage of $60 \mathrm{kWh}$. The specific energy consumption of this system was considered high with $16 \$ / \mathrm{m}^{3}$ production cost.

Carvalho et al. (2004) presented the cost of PV-RO desalination plant with batteries installed in the community of Ceara, of Brazil. The specific energy consumption of produced water was around $3.03 \mathrm{kWh} / \mathrm{m}^{3}$.

Wilf and Klinko (2001) reported that the amount of freshwater that can be recovered from the feed is limited by membrane fouling and scaling. Overall water recovery rates are typically $45-50 \%$ for seawater RO systems, and they can be as high as $90 \%$ in brackish water desalination systems.

A small-scale wind powered RO system was tested by Robinson et al. (1992). Fresh water production by their system was 0.5 to $1 \mathrm{~m}^{3} /$ day, which is the estimated volume needed by a typical remote community in Australia. A pressure vessel to store the feed water under pressure was included. There was no feedback control mechanism for the system operation, and when the available wind power was low, a small diesel or portable gasoline pump was used.

Miranda and Infield (2002) developed a system with a $2.2 \mathrm{~kW}$ wind turbine generator powering a variable-flow RO desalination unit. Operation at a variable flow allows the uncertainty and variability of the wind to be accommodated without need of energy storage. Batteries, which are common in stand-alone systems, are avoided and water production is dependent on the instantaneous wind speed.

The complementary features of wind and solar resources make the use of hybrid wind-solar systems to drive a desalination unit a possible alternative. RO and hybrid solar PV-wind power systems have been designed and implemented, e.g. in the rural areas of the Sultanate of Oman (Al Malki et al., 1998), in Israel (Weiner et al., 2001), in the northern part of Mexico, in a small island on the German coast of the North Sea (Petersen et al., 1981), and at the site of BorjCedria on the southern suburbs of Tunis city (Houcine et al., 1999).

A hybrid wind/photovoltaic power unit connected to a RO desalination plan was implemented on Libya's coast of the Mediterranean Sea (Kershman et al., 2005). The nominal production of the plant was intended to be $300 \mathrm{~m}^{3} /$ day for the supply of a village with potable water. 
The facility design was flexible for the integration of a diesel generator and electrochemical storage.

Mohamed and Papadakis (2004) presented the design of a stand-alone hybrid wind-PV system to power a seawater RO desalination unit, with energy recovery using a simplified spreadsheet model. A daily and monthly simulation and economic analysis were also performed. The calculated fresh water production cost was $5.2 € / \mathrm{m}^{3}$, and the realized energy saving was close to $50 \%$ when a pressure-exchanger-type energy recovery unit was considered.

This study is a part of large project (HYARES) funded by Europe which was structured in the following phases: design of the desalination unit and the solar cells, wind turbine, study of infrastructures, hydraulic and civil engineering works, equipment transportation to the selected in Wadi ELNatrun region, Egypt, installation and starting-up of the whole system, complemented by the practical training of local technicians, and the follow-up and evaluation of the project. The study aim was to monitor the performance of a RO desalination unit for ground water in remote area powered by both PV and wind turbine. The benefits are the desalination units powered by renewable energy systems are uniquely suited to provide water and electricity in remote areas where water and electricity infrastructure is currently lacking.

\section{MATERIALS AND METHODS}

\subsection{Site selection}

The main criteria for site selection were availability of solar energy, sunshine hours and wind speed. The East of EL-Gaar Village at Wadi EL-Natrun, ElBeheara Government, Egypt was selected to install the renewable energy desolation unit due to this site has both predictable wind energy as well as an abundance of sunlight. Wadi EL-Natrun Depression lies at the Western Desert margin of the Delta at latitudes of $30^{\circ} 15^{\prime} 29^{\prime \prime}$ and $30^{\circ} 33^{\prime} 23^{\prime \prime}{ }^{\circ} \mathrm{N}$ and between longitudes of $29^{\circ} 59^{\prime} 17^{\prime \prime}$ and $30^{\circ} 30^{\prime} 50^{\prime \prime}{ }^{\circ} \mathrm{E}$. (Metwally, 2008).

\subsection{System components}

The hybrid renewable energy system in this study was consisted of solar cells (PV), one wind turbine, commercial RO desalination unit, diesel generator, storage batteries and others. The PVs were a thin-film solar cell with a total number of 40 cells grouped in two modules connected in parallel and the 
two modules were connected in series. The PVs were tilted to $25^{\circ}$ faced to south direction. The total power from PVs was $7.2 \mathrm{~kW}$. The wind turbine used in this project is produced about $5 \mathrm{~kW}$. Besides, there was a diesel generator for generating electricity if needed, sunny boy, windy boy and battery inverter were also used. The experimental setup as RO unit was commercial one with capacity of $30 \mathrm{~m}^{3} /$ day. Constructing of the whole system was addressed by expert men according to our design. Figure (1) illustrates the flow diagram of hybrid renewable energy system.

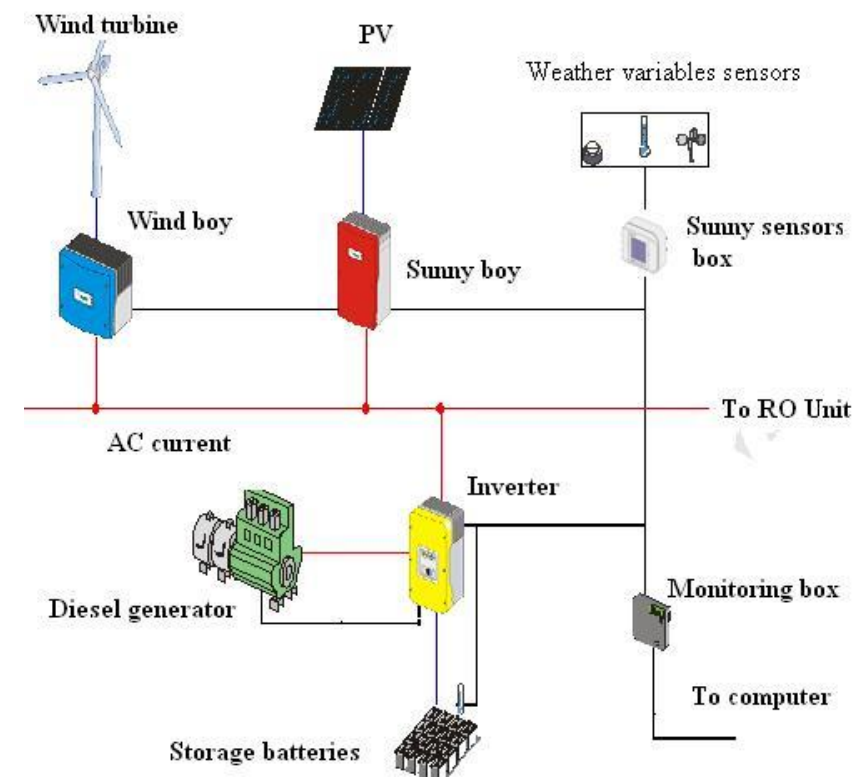

Figure (1). Components of the hybrid renewable energy system for water desalination.

\subsection{PV panel}

The daily energy demand, (kWh/day), from the solar panel is given as (Assad, 2010):

$$
E_{L}=\frac{E_{s}}{\eta_{\text {overall }}}=\frac{W_{f} H}{\eta_{\text {overall }}} .
$$

Where $E_{S}(\mathrm{kWh} /$ day $)$ is the estimated daily energy demand; ךoverall is the overall system efficiency, which is the product of component efficiencies; $W_{f}(\mathrm{~kW})$ is the power rating of the facility; and $\mathrm{H}$ (h/day) is the number of hours the facility is in use per day. The overall system efficiency is given as (Bayod- Rújula and Martínez -Gracia, 2009):

$\eta_{\text {overall }}=\eta_{P V} \eta_{B} \eta_{I N V}$ 
Where $\eta_{\mathrm{PV}}$ is the PV module efficiency; $\eta_{\mathrm{B}}$ is the battery efficiency; and $\eta_{\mathrm{INV}}$ is the inverter efficiency. The PV floor area, $\mathrm{APV}\left(\mathrm{m}^{2}\right)$, can be calculated by the following equation (Abd El-Shafy, 2009):

$$
A_{P V}=\frac{E_{L}}{I_{\text {ave }} T_{C F}}
$$

Where $I_{\text {ave }}\left(\mathrm{kWh} / \mathrm{m}^{2} /\right.$ day) is the average daily energy (solar isolation) input over the year and $\mathrm{T}_{\mathrm{CF}}$ is the temperature correction factor. The PV peak power, $\mathrm{W}_{\mathrm{PVP}}(\mathrm{kW})$, at peak solar isolation $\left(\mathrm{PSI}, \mathrm{kW} / \mathrm{m}^{2}\right.$ ) is given as (Alamsyah et al., 2003):

$$
W_{P V P}=A P V \times P S I \times \eta_{P V}
$$

The total system direct current, $\mathrm{I}_{\mathrm{DC}, \mathrm{sym}}[\mathrm{Ah}]$, needed can be calculated as follows (Assad, 2010):

$$
I_{D C, \text { sym }}=\frac{W_{P V P}}{V_{D C, \text { bus }}}
$$

Where $\mathrm{V}_{\mathrm{DC} \text {,bus }}(\mathrm{V})$ is the $\mathrm{DC}$ bus voltage.

Modules are connected in series and parallel according to the system usage as follows:

The number of PV module in series, $\mathrm{N}_{\mathrm{ms}}$, is obtained as (Bayod-Rújula and Martínez-Gracia, 2009):

$$
N_{m s}=\frac{V_{D C, \text { bus }}}{V_{D C, \bmod }} \text {. }
$$

Where VDC,mod (V) is the PV module rated voltage . However, the string number of modules in parallel, $\mathrm{N}_{\mathrm{mp}}$ (each containing $\mathrm{N}_{\mathrm{ms}}$ ), is given as (Bayod-Rújula and Martínez-Gracia, 2009):

$$
N_{m p}=\frac{I_{D C, s y m}}{I_{D C, \text { mod }}}
$$

Where $\mathrm{I}_{\mathrm{DC} \text {,mod }}(\mathrm{A})$ is the module rated current. Therefore, the total number of modules that make up the panel is given as (Bayod- Rújula and Martínez -Gracia, 2009):

$$
N_{m}=N_{m s} x N_{m p}
$$

According to Oko and Ogoloma (2011) The optimal tilt angle, $\mathrm{s}^{*}$ (o), for a south facing fixed flat plate collector for the geographical location under consideration is given as:

$$
S^{*}=2.9489+1.405 \phi-0.019 \phi^{2},
$$




$$
\text { for } 4.858<\phi<13.0107\left[^{\circ}\right]
$$

Where $\phi\left(^{\circ}\right)$ is the latitude of the location.

\subsection{Wind turbines}

Wind turbine is machine which harness the kinetic energy of the wind to do useful work such as pumping water or generating electricity. A wind turbine absorbs power according to the following equation:

$$
P=0.5 \rho A C p V^{3}
$$

Where $P=$ power generated by the wind turbine $(\mathrm{W}), \rho=$ air density, $\left.\mathrm{kg} / \mathrm{m}^{3}\right)$,

$V=$ wind speed $(\mathrm{m} / \mathrm{s}), A=$ rotor swept area $\left(\mathrm{m}^{2}\right)$ and $C p=$ power coefficient.

\subsection{Storage batteries}

Both wind energy and solar energy were considered as renewable energy sources for the RO unit. The power system would have to include electricity storage, and lead-acid batteries were chosen over nickelcadmium due to lower cost. The storage capacity, $\mathrm{S}_{\mathrm{BC}}(\mathrm{kWh})$, of the battery can be estimated according to the following relation (Mahmoud and Ibrik, 2006):

$$
S_{B C}=\frac{N_{C} E_{S}}{D O D \times \eta_{B}}
$$

Where $\mathrm{N}_{\mathrm{C}}$ (day) is the largest number of continuous cloudy days of the location and DOD is the maximum permissible depth of discharge of the battery. If the total number of batteries, $\mathrm{N}_{\mathrm{B}}$, is obtained as: e dc bus voltage, VDC,bus is known, then one can present the storage capacity in Ampere-hour, $S_{B C}(\mathrm{Ah})$, as:

$$
S_{B C}^{\prime}=\frac{1000 S_{B C}}{V_{D C, \text { bus }}}
$$

Where $S_{1, B C}^{\prime}(\mathrm{Ah})$ is the capacity of one of the batteries selected for the system. With the knowledge of the number of batteries, the connection of the battery bank can then be easily obtained. The number of batteries in series, $N_{B S}$, is given as:

$$
N_{B}=\frac{S_{B C}^{\prime}}{S_{1, B C}^{\prime}}
$$

Where $\operatorname{VDC}, 1 \mathrm{~B}(\mathrm{~V})$ is the voltage rating of one of the batteries selected for 
the system. The number of batteries in parallel, NBP, in string of NBP is given as:

$$
N_{B P}=\frac{N_{B}}{N_{B S}}
$$

\subsection{Experimental work}

The experimental setup as RO unit is designed and constructed in the selected site. Figure (2) illustrates the photo of the experimental RO setup. However, the flow diagram of the experimental RO setup is shown in Figure (3).

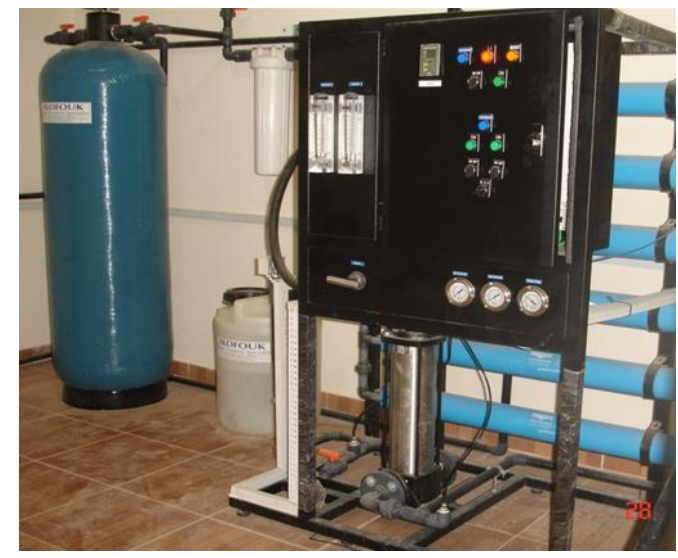

Figure (2). Photo of the experimental RO setup.

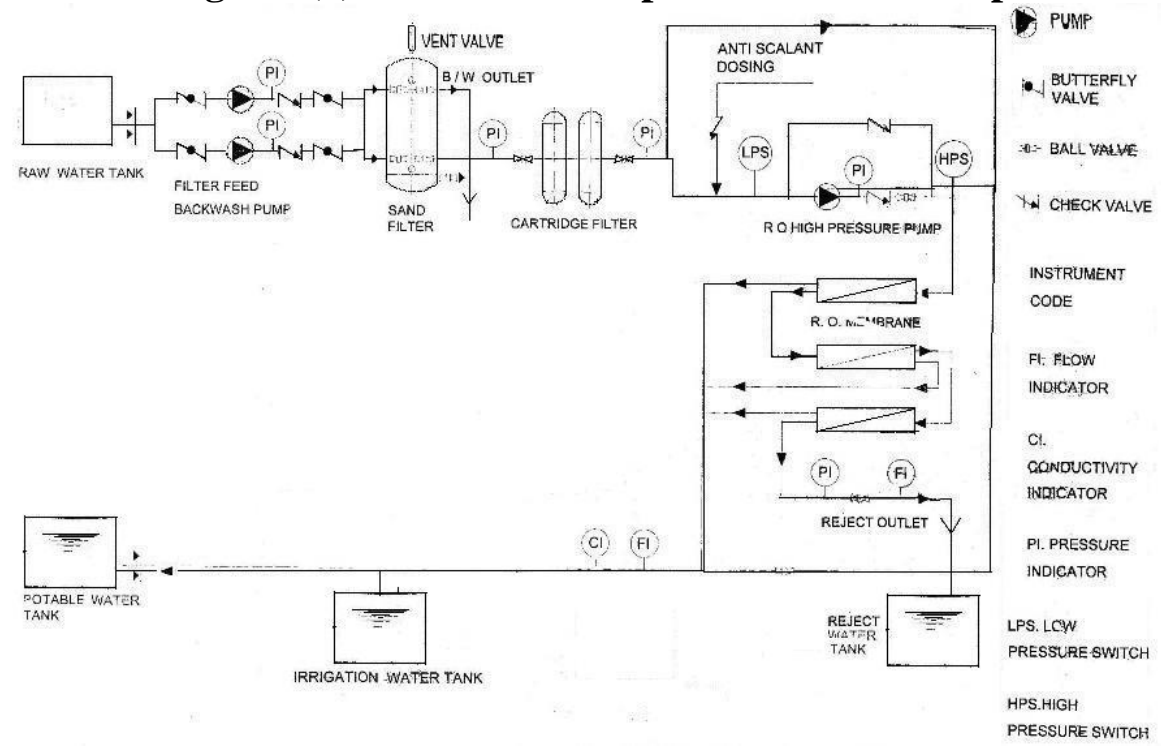

Figure (3). Flow diagram of the experimental setup 
It consists mainly of water tank, feed water pump, sand filter, cartridge water filter, high pressure water pump, RO membrane element assembled unit, piping and control valves. The water tank which is made from polyethylene (capacity $5 \mathrm{~m}^{3}$ ) is open to the atmosphere. The tank is normally full of brackish water that is used as a feed water source to the system. Other tank (capacity $5 \mathrm{~m}^{3}$ ) is used to collect the permeate and the brine is collected in open area.

The raw water flows first through the sand carbon filter to remove any odder. The water is then flows through a cartridge filter to remove solid particles. The high pressure pump is used to supply the membrane element assembled (RO) unit with high pressure feed water. The setup is equipped with a number of valves to control the flow rate through the membrane RO unit. The permeate and drain flow rates are measured with the flow meters. Six membrane elements assembled RO unit. The element is Model WAVE-300 E-4 and maximum operating pressure 21 bar. The pressure is measured by high precision and accurate pressure gauges, while the temperature is measured by a digital thermometer. The brackish water which had concentration of $2291 \mathrm{ppm}$ was fed by the well pump in to the raw water storage tank. Before entering the desalination system, the raw water passes a sand filter and cartridge filter to remove excess turbidity or suspended solids, which may cause problems in pump operation and instrumentation if they enter the RO System. The RO- modules are served by high pressure pump. The feed water is distributed across the membranes by means of transverse stream filtration and by this apart of the water is desalinated as it permeates the membranes. The remaining brine is drained off. The pure water flows from the modules to a storage tank. For further analysis, a data processing a data acquisition system was used to record all variables in Excel sheets. Weather data and solar cell temperature was recorded.

\section{RESULTS AND DISSCUSSION \\ 4.1 Performance analysis of (BSWROU) \\ 4.1.1 Effect of feed temperature}

\subsubsection{Fresh water produced}

Temperature of the feed water has a great impact on the fresh water produced. The temperature was varied due to variation of ambient 
temperature in the location. Figure (4) illustrates average of feed temperature during months of year 2012. Meanwhile, Figure (5) shows average of fresh water produced for months of year 2012. The feed temperature varied from about $16.7^{\circ} \mathrm{C}$ (in winter, December) to $32.4^{\circ} \mathrm{C}$ (in summer, August) as depicted in Figure (4). The water temperatures were 17.4, 21.8, 28.8 and 25.1 ${ }^{\circ} \mathrm{C}$ in January April, July and October months, respectively as representive for winter, spring, summer and autumn seasons. The percent increase through these selected months were $25.3,65.5$ and $44.4 \%$.

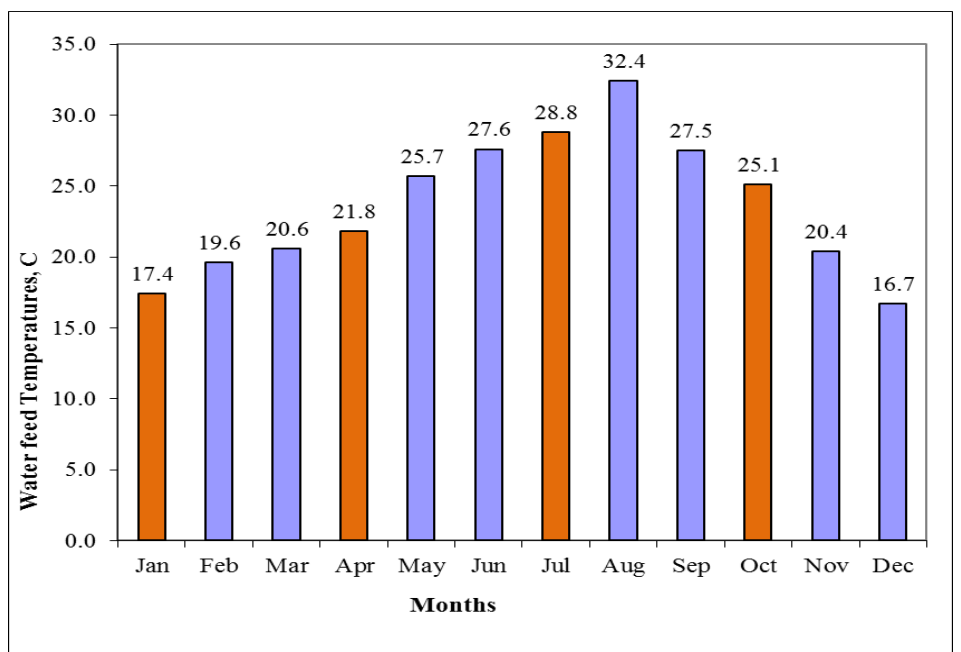

Figure (4). Average of water feed temperature for months of year 2012.

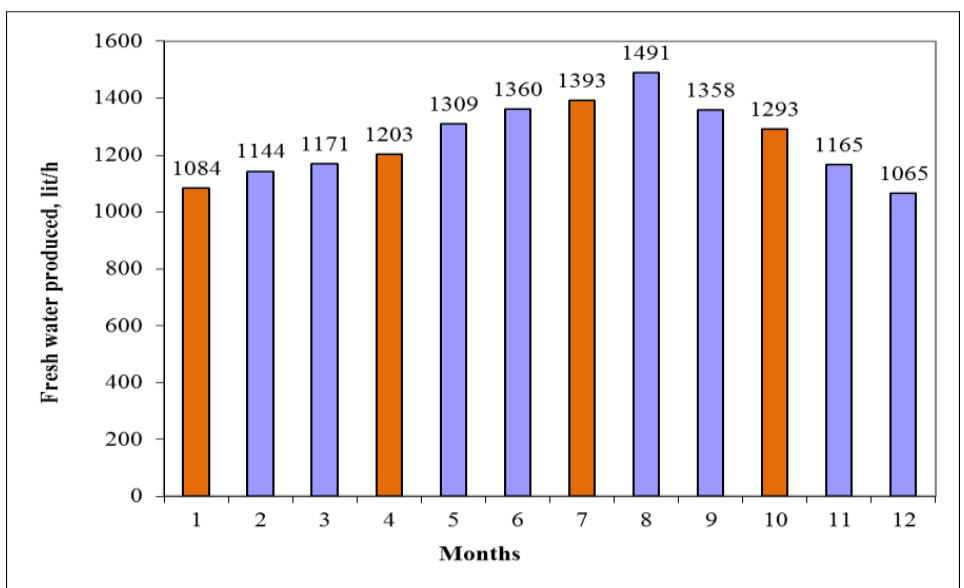

Figure (5). Average of fresh water produced for months of year 2012.

As a result, the fresh water produced increased from 1065 to $1491 \mathrm{lit} / \mathrm{h}$ in December and August, respectively. Meanwhile they were 1084, 1203, 
1393 and 1293 in the selected moths, respectively. The increases of percent in fresh water produced over January month were 10.9, 28.5 and $19.3 \%$ due to the increase in water temperature at April, July and October, respectively. It is evident that fresh water produced increase with feed water temperature for the monitored range of temperature recorded in this work. This is attributed to the effect of the temperature of the feed water. As this temperature increases (Hawlader et al., 2001), this will decrease the net driving pressure due to the increase in osmotic pressure and, on the other hand, will lead to increasing in water permeability coefficient due to the decrease in both viscosity and density and the later one will overcome the effect of net driving pressure thus the fresh water produced is increased as reported by Al-Bastaki and Al-Qahtani (1994). Goosen et al. (2002) reported that increasing in the rate of fresh water produced through the membrane as the feed water temperature increases since the viscosity of the solution is reduced and higher diffusion rate of water through the membrane is obtained. There was up to a $60 \%$ increase in the permeate flux when the feed temperature was increased from 20 to $40^{\circ} \mathrm{C}$.

\subsubsection{Recovery ratio}

The ratio of the amount of permeate produced by the RO relative to the amount of feed going to the $\mathrm{RO}$ is called the recovery ratio (RR) or system efficiency. Recovery ratio is extremely important in regard to RO performance (Gabr, 2007). However, the permeate recovery is important parameter in the design and operation of the RO systems. Recovery ratio is the ratio of conversion of the feed water, $Q_{f}$, to product or (permeate), $Q_{w}$, and is defined as:

$$
R R=\frac{Q_{W}}{Q_{f}} \times 100
$$

The effect of temperature of the feed water on recovery ratio was depicted in Figure (6) for the all months and average of recovery ratio for January was depicted in Figure (7). It is evident that recovery ratio increase with feed water temperature for the monitored range of temperature recorded in this work. 


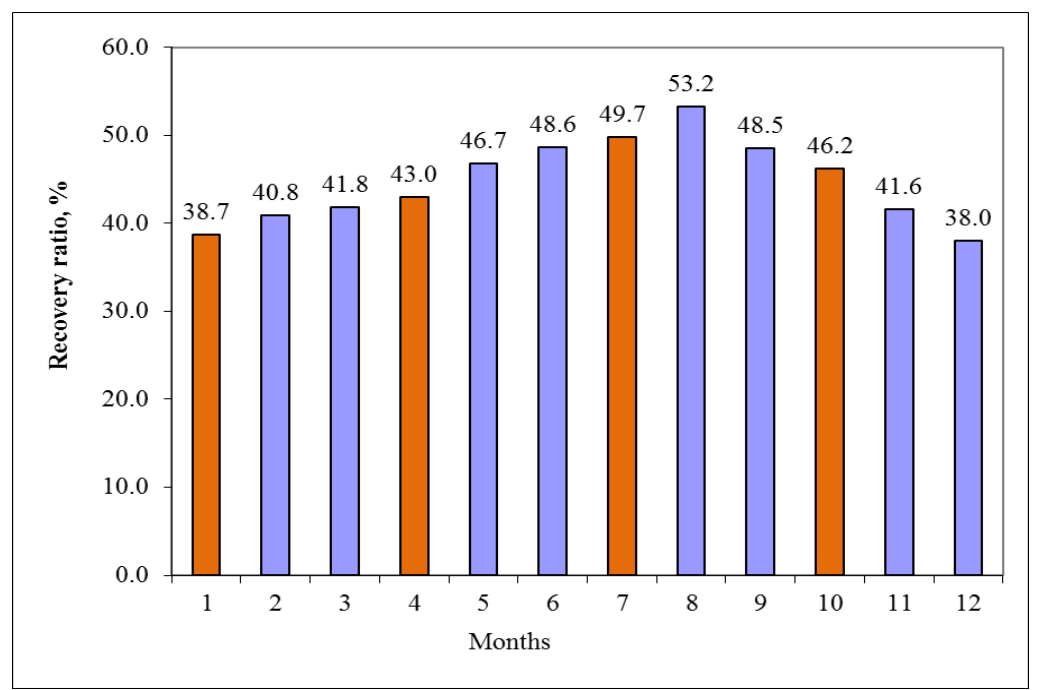

Figure (6). Effect of feed temperature on recovery ratio for months of

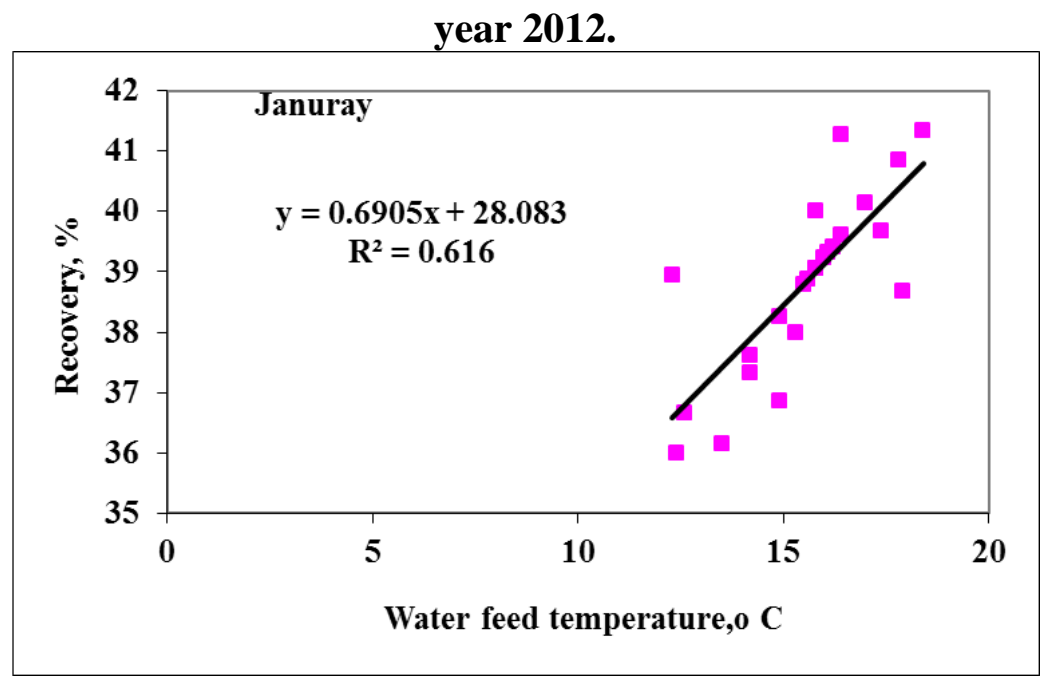

Figure (7). Average of recovery ratio for January month of year 2012.

The recovery ratio ranged from 38.0 to $53.2 \%$ in December and August months. While, they were 38.7, 43.0, 49.7 and 46.2\% through the selected months, respectively. The percent increases in the recovery ratio over January month due to increasing the water feed temperature were 11.1, 28.4 and 19.2\%, at April, July and October months, respectively. The effect of feed water temperature on recovery was also seen by Joshia et al. (2012). As the temperature of feed water increases, the net driving pressure decreases due to an increase in osmotic pressure and this leading 
to overall increase in recovery ratio (Al-Bastaki and Al-Qahtani, 1994; Hawlader et al., 2000 and 2001).

\subsubsection{Concentration factor}

Recovery ratio can be used to get concentration factor. However, the concentration factor is related to the RO system recovery and is an important equation for RO system design. The more water you recover as permeate (the higher the recovery percent), the more concentrated salts and contaminants you collect in the concentrate stream. This can lead to higher potential for scaling on the surface of the RO membrane when the concentration factor is too high for the system design and feed water composition. The concentration factor (CF) could be calculated as follows:

$$
C C F \%=\frac{100}{100-R R}
$$

The average of concentration factor for months of year 2012 is shown in Figure (8).

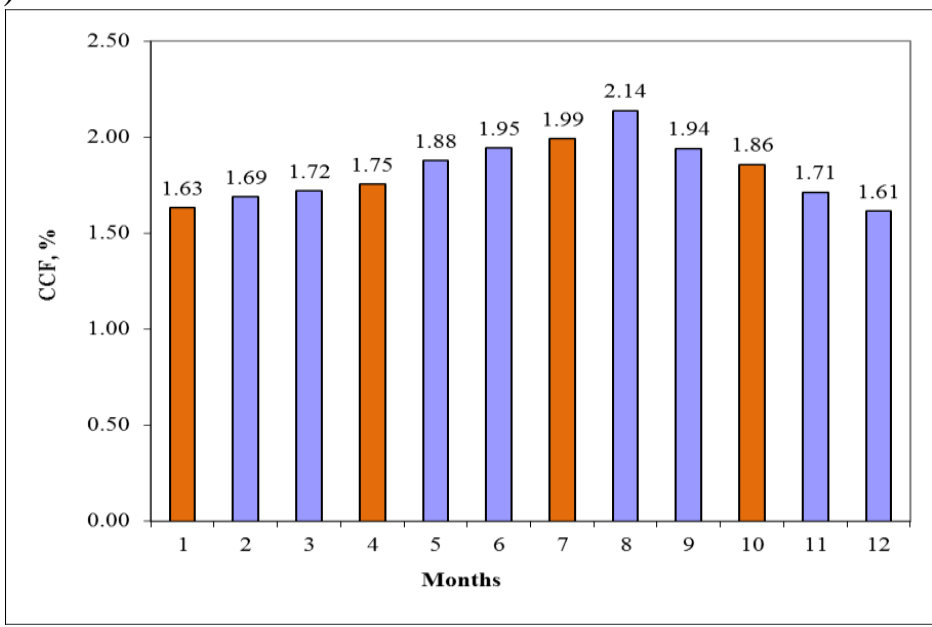

Figure (8). The average of concentration factor for months of year 2012

\subsubsection{Relationship between fresh water produced and specific energy} consumption during desalination process

The specific energy consumption for the all months of year 2012 is illustrated in Figure (9). The specific energy consumption is typically ranged between 2.21 and $3.10 \mathrm{kWh} / \mathrm{m}^{3}$ throughout the year of experiment with an average of $2.7 \mathrm{kWh} / \mathrm{m}^{3}$. 


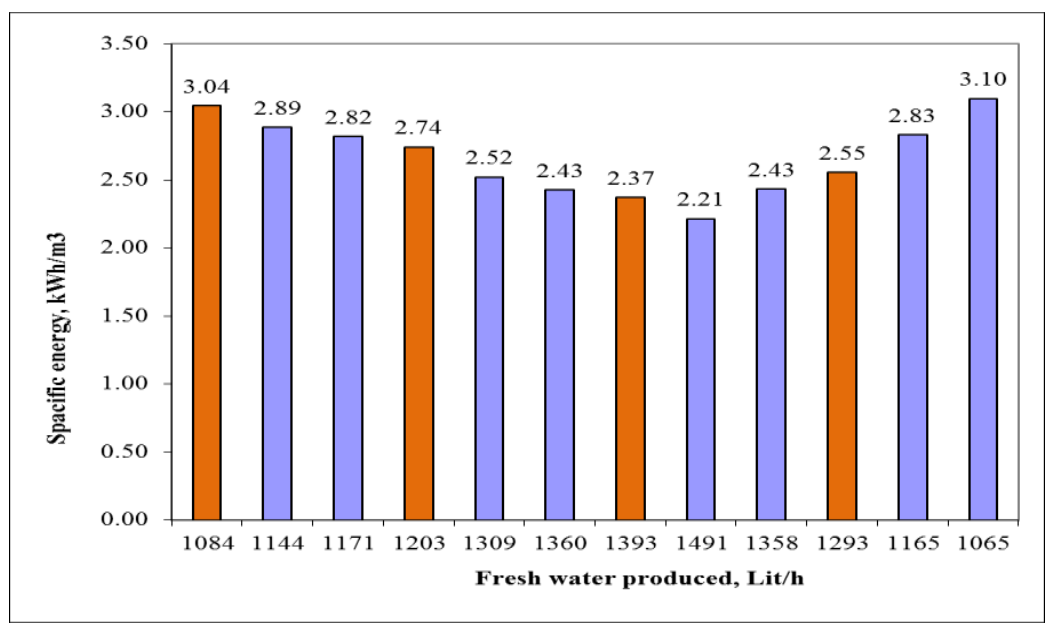

Figure (9). The specific energy consumption for the all months of year 2012.

In previous study, energy consumption of common desalination processes such as Thomson (2003) who reported that specific energy consumption (photovoltaic-electricity) was between 3.2 and $3.7 \mathrm{kWh} / \mathrm{m}^{3}$ for the desalination of sea water depending on the solar irradiance and feed water temperature.

\section{CONCLUSION}

Performance of a wind-solar reverse osmosis unit for brackish water desalination in remote area of Wadi EL-Natrun region in Egypt was investigated. However, the operation parameters of the developed brackish solar-wind reverses osmosis unit were limited. The performance of the unit was evaluated using energy consumption for producing fresh water $\left(\mathrm{kWh} / \mathrm{m}^{3}\right)$, percent recovery $(\%)$ and concentration factor $(\%)$. The average values of these criteria during operation in year of 2012 were $2.7 \mathrm{kWh} / \mathrm{m}^{3}, 44.7 \%$ and $1.82 \%$, respectively. It is evident that these values demonstrated good operation of the developed unit.

\section{REFERENCES}

Abd El-Shafy, A.N. (2009). Design and economic analysis of a stand-alone PV system to electrify a remote area household in Egypt. The Open Renewable Energy Journal, 2: 33-37.

Abou Rayan, M., B. Djebedjian and I. Khaled (2004). Evaluation of the effectiveness and performance of desalination equipment in Egypt. Eighth 
PROCESS ENGINEERING

International Water Technology Conference, IWTC8 2004, Alexandria, Egypt:653-668.

Ahmad, G. and J. Schmid (2002). Feasibility study of brackish water desalination in the Egyptian deserts and rural regions using PV systems. Energy Conversion and Management. 43: 2641-2649.

Al Bazedi, Gh., R.S. Ettouney and S. R. Tewfik (2012). Simulation and optimization of large scale desalination plants: A case study for South Mediterranean coast. Journal of Indian Water Works Association, 44 (1): 59-66.

Al Malki, A., M. Al Amri and H. Al Jabri (1998). Experimental study of using renewable energy in the rural areas of Oman, Renewable Energy, 14:319324.

Alamsyah, T.M.I., K. Sopian and A. Shahrir (2003). In techno economics analysis of a photovoltaic system to provide electricity for a household in Malaysia. Proceedings in International Symposium on Renewable Energy: Environment Protection \& Energy Solution for Sustainable Development, Kuola Lumpur, 387-396.

Al-Bastaki, N. M. and H.I. Al-Qahtani (1994). Assessment of the thermal effects on the reserve osmosis of salt/water solution by using a spiral wound membrane.Desalination,99:159-168.

Assad, A. (2010). A stand-alone photovoltaic system, case study: a residence in Gaza. J. of Applied Sciences in Environmental Sanitation, 5 (1): 81-91.

Banat, F., H. Qiblawey and Q. Al-Nasser (2012). Design and operation of small-scale photovoltaic-driven reverse osmosis (PV-RO) desalination plant for water supply in rural areas. Computational Water, Energy, and Environmental Engineering,1:31-36.

Barron, O. (2006). Desalination options and their possible implementation in Western Australia. CSIRO National Research Flagship Initiative, $37 \mathrm{p}$. 
Bayod-Rjula, A.A. and A. Martinez-Gracia (2009). Photovoltaic system for brackish water desalination by electrodialysis and electricity generation. Desalination and Water Treatment:142-151.

Carvalho, P., D. Riffel, C. Freire and F. Montenegro (2004). The Brazilian experience with a photovoltaic powered reverse osmosis plant. Progress in Photovoltaic's, 12(5):373-385.

Charcosset, C. (2009). A review of membrane processes and renewable energies for desalination. Desalination, 245:214-231.

Compain, P. (2012). Solar Energy for Water desalination. Procedia Engineering, 46:220- 227.

E1-Kady, M. and F. E1-Shibini (2001). Desalination in Egypt and the future application in supplementary irrigation . Desalination, 136: 63-72.

Gabr, I. K. E. (2007). Experimental and numerical optimization of reverse osmosis desalination plant. PhD Thesis, Mechanical Power Engineering dept., Faculty of Engineering, Mansoura University.

Goosen, M., H. Mahmoudi, N. Ghaffour and S.S. Sablani (2011). Application of renewable energies for water desalination, desalination, trends and technologies, Michael Schorr (Ed.), ISBN: 978-953-307-311-8, In Tech, Available from: http://www.intechopen.com.

Goosen, M.F.A., S.S. Sablani, S.S., Al-Maskari, R.H. Al-Belushi and M. Wilf (2002). Effect of feed temperature on permeate flux and mass transfer coefficient in spiral-wound reverse osmosis systems. Desalination, 144:367-372.

Hawlader, M.N.A., J.C. Ho and K.T. Chua (2001). An experiment with spiral wound reverse osmosis membrane for the desalination of seawater. ASEAN Journal on Science and Technology for Development, 18(1):35-44.

Herold, D., and A. Neskakis (2001). A small PV-driven reverse osmosis 
PROCESS ENGINEERING

desalination plant on the island of Gram-Canaria. Desalination, 137: 285-292.

Houcine, I., F. Benjemaa, M.H. Chahbani and M. Maalej (1999). Renewable energy sources for water desalting in Tunisia, Desalination, 125:123-132.

Hunter, R. and G. Elliot (1994). Wind Diesel Systems, Cambridge University Press, 1994.

Ismail, M.S., M. Moghavvemi and T.M.I. Mahlia (2012). Design of a $\mathrm{PV} /$ diesel stand alone hybrid system for a remote community in Palestine. Journal of Asian Scientific Research 2(11):599-606.

Joshia, H., R. Bansala, M.N.A. Hawlader (2012). Remediation of Salinity in Ground Water through RO Membranes. International Journal of Chemical and Environmental Engineering December, 3(6):401-405.

Kershman, S.A., J. Rheinlnder, T. Neumann and O. Goebel (2005). Hybrid wind/PV and conventional power for desalination in LibyaGECOL's facility for medium and small scale research at Ras Ejder, Desalination, 183:1-12.

Liu, C. C. K., J.-W. Parkb, R. Migita and G. Qin (2002). Experiments of a prototype wind-driven reverse osmosis desalination system with feedback control. Desalination, 150: 277-287.

Mahmoud, M.M. and I.H. Ibrik (2006). Techno-economic feasibility of energy supply to remote villages in Palestine by PV-systems, diesel generator and electric grid. Renewable Sustainable Energy Review, 10: $128-138$.

Mahmoudi, H., S.A. Abdul-Wahab, M.F.A. Goosen, S.S. Sablani, J. Perret, A. Ouagued and N. Spahis (2008).Weather data and analysis of hybrid photovoltaic-wind power generation systems adapted to a seawater greenhouse desalination unit designed for arid coastal countries. Desalination, 222:119-127.

Metwally, M. S. S. (2008). Environmental changes in Wadi EL Natrun 
Depression: an applied geographical using geographical information system \& remote sensing (G.I.S \& R.S).

Miranda, M.S. and D. Infield (2002). A wind-powered seawater reverseosmosis system without batteries, Desalination, 153: 9-16.

Mohamed, E.S. and G. Papadakis (2004). Design, simulation and economic analysis of a stand-alone reverse osmosis desalination unit powered by wind turbines and photovoltaic's, Desalination, 164:87-97.

Oko, C.O.C. and O.B. Ogoloma (2011). Generation of typical meteorological year for port harcourt zone. Journal of Engineering Science and Technology, 6(2): 204-214.

Petersen, G., S. Fries, J. Mohn and A. Müller (1981). Wind and solar powered reverse osmosis desalination units -Design, start up, operating experiences, Desalination, 39:125-135.

Phuse, S.S. and R.S. Shelke (2012). Water purification system for remote areas using photovoltaic. International Journal of Engineering Research and Applications (IJERA), 2 (4):2014-2018.

Robinson, R., G. Ho and K. Mathew (1992). Development of reliable low-cost reverse osmosis desalination unit for remote communities, Desalination, 86:9-26.

Russel, R. (2009). Development of an artificial neural network model for predicting the performance of a reverse osmosis (RO) unit. MSc Thesis, Curtin University of Technology:175p.

Thomson, M. A. (2003). Reverse osmosis desalination of seawater powered by photovoltaic without batteries. $\mathrm{PhD}$ Thesis, Loughborough University, Leicestershire, UK.

Thomson, M. and D. Infield (2005). Laboratory demonstration of a photovoltaic-powered seawater reverse osmosis system without batteries. Desalination, 183:105-111. 
Weiner, D., D. Fisher, E.J. Moses, B. Katz and G. Meron (2001). Operation experience of a solar- and wind-powered desalination demonstration plant. Desalination, 137:7-13.

Wilf, M. and K. Klinko (2001). Optimization of seawater RO systems design. Desalination, 138:299-306.

Xiao, G., X. Wang, M. Ni, F. Wang, W. Zhu, Z. Luo and K. Cen (2013).A review on solar stills for brine desalination. Applied Energy, 103: 642-652.

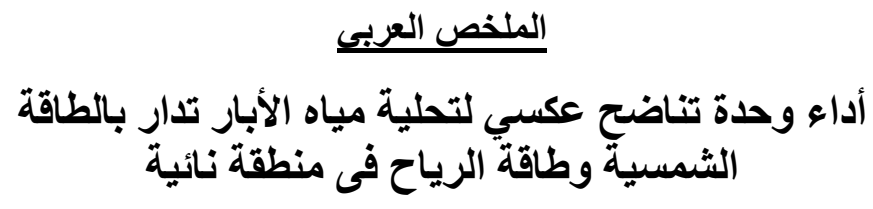

سميرة شلبي قاسم' عبد الحمي زكريا شكر بليمان نصيف سليمان` جورج باباداكس

تهدف هذه الدر اسة إلى رصد أداء وحدة تناضح عكسي لتحليه مياه جوفية قلبلة الملوحة تعتمد في تشغيلها على الطاقة الكهربية المنتجة من الخلايا الثمسية وتوربينات الريـاح في منطقة نائيسة من مصر ، مع اعتبار أن هذه الدراسـة هي جزء من مشروع كبير يسمى HYARES تمويله من

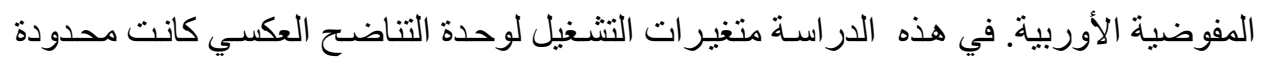
حيث ضغط التتغيل، وملوحة المياه ودرجة الحموضة ثوابت. وبسبب ضخامة البيانات المسجلة

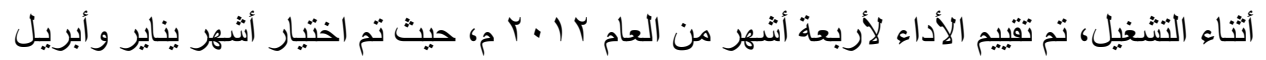
ويوليو و أكتوبر لتمثيل فصل الثتاء، الربيع، الصبف، الخريف على الترتيب. تم تقييم أداء الوحدة باستخدام معايير مختلفة. و هذه المعايير هي استهلاك الطاقة لإنتاج المياه، ونسبة استعادة المياه

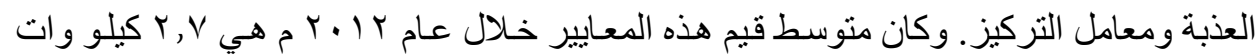

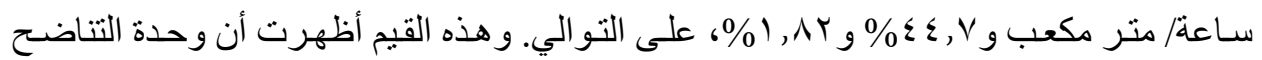
العكسي المدارة بالثمسية وطاقه الرياح معا جيدة التشغيل في منطقة التجارب التهارب بوادي النطرون

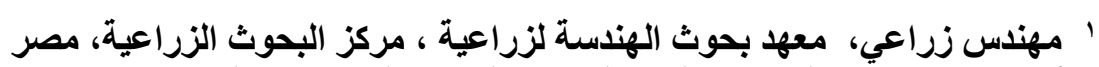

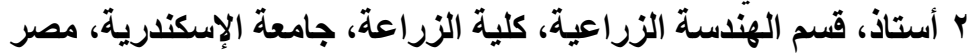

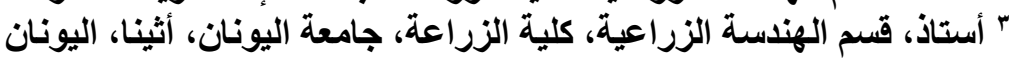

